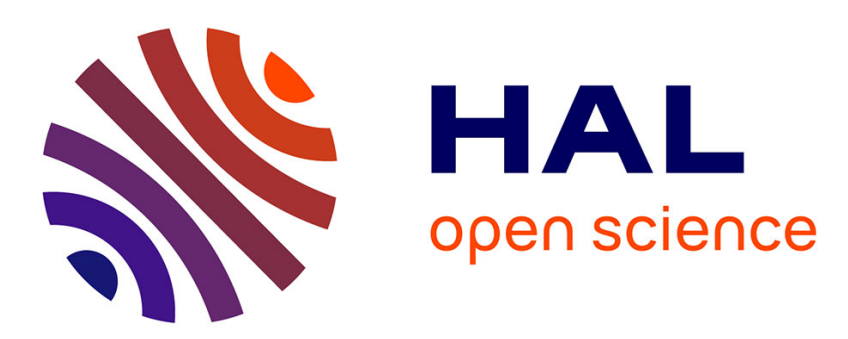

\title{
Low light acclimation in five temperate broad-leaved tree species of different successional status: the significance of a shade canopy
}

Nicole Legner, Stefan Fleck, Christoph Leuschner

\section{To cite this version:}

Nicole Legner, Stefan Fleck, Christoph Leuschner. Low light acclimation in five temperate broadleaved tree species of different successional status: the significance of a shade canopy. Annals of Forest Science, 2013, 70 (6), pp.557-570. 10.1007/s13595-013-0298-4 . hal-01201502

\author{
HAL Id: hal-01201502 \\ https://hal.science/hal-01201502
}

Submitted on 17 Sep 2015

HAL is a multi-disciplinary open access archive for the deposit and dissemination of scientific research documents, whether they are published or not. The documents may come from teaching and research institutions in France or abroad, or from public or private research centers.
L'archive ouverte pluridisciplinaire HAL, est destinée au dépôt et à la diffusion de documents scientifiques de niveau recherche, publiés ou non, émanant des établissements d'enseignement et de recherche français ou étrangers, des laboratoires publics ou privés. 


\title{
Low light acclimation in five temperate broad-leaved tree species of different successional status: the significance of a shade canopy
}

\author{
Nicole Legner • Stefan Fleck • Christoph Leuschner
}

Received: 14 November 2012 / Accepted: 21 May 2013 /Published online: 13 June 2013

(C) INRA and Springer-Verlag France 2013

\begin{abstract}
- Context Tree species differ largely in their capability to produce characteristic shade leaves with effective morphological and physiological acclimation to low light.

- Aims By examining the sun/shade leaf differentiation in leaf morphology, foliar nitrogen and photosynthetic capacity in five temperate tree species of different successional status, we aimed at identifying those leaf traits that determine the development of a typical shade crown with low lightacclimated leaves.

- Methods Leaf morphology, foliar N content, photosynthetic capacity $\left(V_{\text {cmax }}, J_{\max }\right.$ and $\left.A_{\text {max }}\right)$ and leaf dark respiration $\left(R_{\mathrm{d}}\right)$ were measured in the canopies of 26 adult trees of Fraxinus, Acer, Carpinus, Tilia and Fagus species.

- Results Six traits (the sun/shade leaf differentiation in specific leaf area, leaf size, $A_{\max }$ per leaf area or per mass, photosynthetic $\mathrm{N}$ use efficiency and $R_{\mathrm{d}}$ ) were found to characterise best the degree of low light acclimation in shade
\end{abstract}

Handling Editor: Erwin Dreyer

Contribution of the co-authors SF developed the study design, NL conducted the research, NL with support from SF conducted the analysis, and CL, NL and SF wrote the paper.

N. Legner $\cdot$ S. Fleck $\cdot$ C. Leuschner $(\triangle)$

Plant Ecology and Ecosystems Research, Albrecht von Haller Institute for Plant Sciences, University of Göttingen,

Untere Karspüle 2, 37073 Göttingen, Germany

e-mail: cleusch@gwdg.de

S. Fleck

Intensive Environmental Monitoring, Department of Environmental

Control, Nordwestdeutsche Forstliche Versuchsanstalt

Grätzelstr. 2, 37079 Göttingen, Germany

Present Address:

N. Legner

Division of Agronomy, Department of Crop Sciences, University

of Göttingen, Göttingen, Germany leaves. All five species exhibited certain modifications in leaf morphology and/or physiology in response to low light; Fagus sylvatica showed the highest and Fraxinus excelsior the lowest shade leaf acclimation.

- Conclusions Our results indicate that the five early/midto late-successional species have developed species-specific low light acclimation strategies in their shade crowns which differ in terms of the relative importance of leaf morphological and physiological acclimation.

Keywords $A_{\max } \cdot$ Fagus sylvatica $\cdot$ Fraxinus excelsior . $J_{\max } \cdot$ Mature trees $\cdot$ SLA $\cdot$ Tilia cordata $\cdot V_{\text {cmax }} \cdot$ Acer pseudoplatanus · Carpinus betulus . Photosynthetic capacity $\cdot$ Sun/shade leaf dichotomy

\section{Introduction}

Mixed forests are composed of tree species with often largely different size, structure, phenology and functioning of their canopies. These features control the growth rate and competitive success of the species in the stand. The degree of morphological and functional dissimilarity in the canopies of mixed forest species also determines whether complementarity in light use does occur or not. However, the study of functional differences among co-occurring tree species in mixed forests is still at its infancy, mostly because canopy access is inherently difficult.

A number of partly competing functional classification systems for temperate and tropical trees have been proposed. A widely used approach focuses on the light requirement for regeneration and distinguishes between shade-tolerant species that can not only germinate and successfully survive in the shade but also grow there to maturity, and light-demanding species that can survive in the canopy shade as seedlings and saplings but need gaps to grow to full size (e.g. Liburnau 1908, Popma et al. 1992). Alternatively, tree species could 
be grouped according to the functional properties of adult instead of juvenile trees; relevant traits could be the withincanopy light gradient and the degree of morphological and functional differentiation between a tree's sun and shade canopy. The existence of a distinct shade canopy may be decisive in competitive interactions because it determines light transmissivity to the ground, and trees with a distinct shade canopy may be more productive than trees lacking typical shade leaves (Sims et al. 1994) as the former typically produce larger stand leaf areas (Ellenberg and Leuschner 2010). We argue that the capability of a tree to form a typical shade canopy does represent a key functional trait determining the life cycle, productivity, stress tolerance and successional status of a species.

The sun leaves in the uppermost crown and the shade leaves at the crown base represent extremes of a continuum of intracanopy modification in leaf morphology and physiology along the vertical light gradient. With decreasing light availability from canopy top to base, leaf thickness generally decreases and specific leaf area (SLA, leaf area per mass) increases. Since nitrogen content per leaf mass $\left(N_{\mathrm{m}}\right)$ typically changes only little with light availability in the canopy, $\mathrm{N}$ content per area $\left(N_{\mathrm{a}}\right)$ decreases in parallel with increasing SLA from the sun to the shade crown (Niinemets 2007). Due to the close link between photosynthetic capacity and $N_{\mathrm{a}}$ (Niinemets 2007), lightsaturated net photosynthesis rate $\left(A_{\max }\right)$ and its partial determinants maximum carboxylation rate $\left(V_{\text {cmax }}\right)$ and maximum electron transport rate $\left(J_{\max }\right)$ typically decrease from the upper sun to the lower shade crown. Niinemets et al. (1998) concluded from analyses in four temperate deciduous woody species that the light-dependent acclimation of SLA, and not vertical gradients in $\mathrm{N}$ partitioning, is the key determinant of photosynthetic capacity within the crown of woody plants. However, it is not well studied how light-dependent within-crown gradients of leaf morphology and photosynthetic capacity are differing among coexisting tree species and what biological attributes are determining these patterns of functional intra-canopy differentiation. Nonetheless, the analysis of determinants and constraints of light-dependent plasticity in leaf morphology and physiology in coexisting tree species is of great importance for a mechanistic understanding of canopy interactions and complementary light use in mixed stands. Tree ecophysiology seeks a functional grouping of tree species which should include a categorisation of the light capture and light utilisation patterns of different trees. The first steps in this direction are several comparative studies conducted mostly in tropical trees (e.g. Popma et al. 1992).

Species-rich Central European broad-leaved forests of the Carpinion alliance (oak-hornbeam forests) may contain up to eight mid- to late-successional broad-leaved tree species of the genera Carpinus, Quercus, Acer, Tilia, Fagus and Fraxinus that are known to differ significantly in light demand, photosynthetic capacity, maximum growth rate and shade tolerance (Bazzaz 1979; Ellenberg and Leuschner 2010). Thus, light capture and carbon assimilation and their spatial distribution in the canopy should differ significantly among these species or genera indicating that a certain degree of complementarity in light interception and canopy space occupation in these communities must exist.

We used a mobile 30-m lifter in a species-rich old-growth Carpinion forest to gain access to the sun and shade canopies of 26 mature trees of five tree species (genera Fagus, Fraxinus, Tilia, Acer and Carpinus) in order to compile a comprehensive data set on leaf morphological and photosynthetic traits that would allow a functional comparison of the canopies of these species. The five tree species differ markedly in terms of shade tolerance in the regeneration stage (moderate to very high), successional status (early/mid- to late-successional), canopy architecture and physiological constitution.

We searched for traits suited to describe shade canopy properties in quantitative terms and to compare the species with respect to photosynthetic light use in their shade crown. The specific aims of the study were as follows: (1) to compare the five species with respect to the morphology and photosynthetic capacity of their sun and shade leaves, (2) to identify morphological and physiological traits with a high indicative value of the functional differentiation between the sun and shade canopy and (3) to rank the species according to the degree of sun/shade canopy differentiation.

\section{Materials and methods}

\subsection{Study site and tree species}

The study was conducted in a temperate old-growth mixed deciduous forest composed of 5 to 14 tree species per hectare. The forest is located on the south-eastern side of the Hainich mountain range in western Thuringia, Germany, and consists of the largest unfragmented deciduous forest area in Germany with a size of $160 \mathrm{~km}^{2}$, of which a part is protected as Hainich National Park. The study plot is a transect of approximately $200 \mathrm{~m}$ length and $30 \mathrm{~m}$ width located in the southeast of the national park near the village Weberstedt close to the location Thiemsburg (51 $\left.05^{\circ} 00^{\prime \prime} \mathrm{N}, 10^{\circ} 30^{\prime} 27^{\prime \prime} \mathrm{E}\right)$ at $350 \mathrm{~m}$ a.s.l. The soil type is a Luvisol developed from loess over Triassic limestone. The topsoil is free of carbonates and has a $\mathrm{pH}$ $\left(\mathrm{H}_{2} \mathrm{O}\right)$ in the range of 4.5 to 6.8 (Christina Langenbruch, personal communication). The Hainich forest consists of limestone beech forests (Hordelymo-Fagetum community), beech forests on moderately acid soils (Galio-Fagetum community) and mixed oak-hornbeam forests (Stellario-Carpinetum community) with Fagus sylvatica L. (European beech) being the most widespread and abundant species. Locally, as at the Thiemsburg site, beech is only a subordinate member of the community with Tilia cordata Mill. (small-leaved lime), Carpinus betulus L. (European hornbeam), Fraxinus excelsior 
L. (European ash) and Acer pseudoplatanus L. (sycamore maple) being more abundant. Other tree taxa in this forest are additional Tilia and Acer species and members of the genera Prunus, Ulmus, Quercus and others. The forest has been subjected to a selective cutting regime in the past, but the impact of forestry was low during the last three decades and totally ceased in 1997 with the declaration of a national park. The age of the trees ranges between 80 and 120 years.

Photosynthesis measurements were conducted in the crowns of adult Fagus sylvatica, Fraxinus excelsior, $T$. cordata, A. pseudoplatanus and C. betulus trees using a mobile lifter (Denka Lifter model DL30, Rotlehner Arbeitsbühnen $\mathrm{GmbH}$, Massing-Oberdietfurt, Germany). The five species occur at the study site with individuals of similar demographic status in direct neighbourhood to each other. We selected five trees per species (Fraxinus excelsior: six) that had representative diameter at breast height (DBH) and tree height dimensions for the stand (Table 1). All 26 trees were adult codominant individuals that reached with their sun crown the upper sun-lit canopy layer of the stand. Tree height was measured with a Vertex inclinometer (Vertex IV, Haglöf Inc., Langsele, Sweden); DBH was recorded with D1 dendrometer bands (UMS, Munich, Germany).

The five species differ not only with respect to their systematic position (five families) but also in terms of light demand, shade tolerance, height growth, successional status and other traits (Table 2). Mainly based on the existing information about the species' capability to cast shade at maturity (i.e. crown transmissivity) and their successional status in natural forest dynamics (Ellenberg and Leuschner 2010), we arranged the five species in all figures and tables in the sequence Fraxinus excelsior-A. pseudoplatanus-C. betulus-T. cordata-Fagus sylvatica.

The weather conditions of the two study years were similar with respect to temperature but differed in rainfall. The mean air temperature in 2008 was $9.5^{\circ} \mathrm{C}\left(14.6{ }^{\circ} \mathrm{C}\right.$ in the growing season from April 1 to Sep 30) and $8.9^{\circ} \mathrm{C}\left(15.1^{\circ} \mathrm{C}\right)$ in 2009 (weather station Weberstedt/Hainich, meteomedia). The vegetation period in 2008 was relatively dry $(234 \mathrm{~mm})$ and that of 2009 relatively moist $(469 \mathrm{~mm})$; the annual rainfall totals were 500 and $774 \mathrm{~mm}$.

Table 1 Characteristics of the 26 examined tree individuals of five species (means $\pm \mathrm{SE}$ )

\begin{tabular}{llll}
\hline Tree species & $\begin{array}{l}\text { No. of tree } \\
\text { individuals }\end{array}$ & $\begin{array}{l}\text { Tree height } \\
{[\mathrm{m}]}\end{array}$ & DBH [cm] \\
\hline Fraxinus excelsior & 6 & $27.6 \pm 0.9$ & $36.2 \pm 2.6$ \\
Acer pseudoplatanus & 5 & $30.3 \pm 0.9$ & $58.3 \pm 7.1$ \\
Carpinus betulus & 5 & $26.7 \pm 0.7$ & $45.8 \pm 4.7$ \\
Tilia cordata & 5 & $27.0 \pm 1.1$ & $43.5 \pm 5.8$ \\
Fagus sylvatica & 5 & $29.5 \pm 0.6$ & $50.0 \pm 3.2$ \\
\hline
\end{tabular}

$D B H$ diameter at breast height

\subsection{Sampling design}

The mobile lifter allowed reaching the upper sun canopies of all trees at $30 \mathrm{~m}$. The lifter could be moved along the $200-\mathrm{m}$ long transect to access the sun and shade canopies of all 26 trees for in situ gas exchange measurements. The five (six) trees per species were treated as true replicates because they were at least $10 \mathrm{~m}$ (in most cases $>20 \mathrm{~m}$ ) apart from each other except for two ash trees $(5 \mathrm{~m})$. Because we aimed at comparing the five species with respect to the magnitude of the sun - shade leaf difference in morphology and physiology, we examined in a first step the vertical gradient of leaf morphology and photosynthetic capacity in all 26 trees by measuring leaves in the sun canopy, the mid canopy and the lowermost canopy and related the data to canopy openness in the canopy. Thus, each one leaf per tree was investigated in situ for the light and $\mathrm{CO}_{2}$ responses of photosynthesis in the fully sun-lit upper canopy, the partly shaded intermediate crown and in the fully shaded lower crown resulting in five replicates studied per tree species and canopy position (in T. cordata, six sun leaf replicates; in Fagus sylvatica and A. pseudoplatanus, the data of one sun and one shade leaf had to be omitted resulting in only four replicates). Thus, 15 leaves per species were investigated. All measurements were done on sunny or overcast days ( 8 am to $5 \mathrm{pm}$ ) in the summers 2008 (Jun 20-Aug 22) and 2009 (May 29-Aug 29). Based on a plot of SLA against canopy openness (CO; Fig. 2), we defined typical sun leaves as leaves that were exposed to direct sun light for most of the day (i.e. they were not overtopped by other leaves) which referred to $\mathrm{CO}$ values of 40 to $70 \%$. In the case of beech with its rough upper canopy surface, a few sun leaves were found at a canopy openness of only $40 \%$ even though they were not overtopped by other leaves. From the SLA-CO plot, we defined typical shade leaves as leaves with $\mathrm{CO}$ values $<15 \%$. In the subsequent comparison of sun and shade leaves, we omitted all leaves from the middle crown.

\subsection{Gas exchange measurements and hemispherical photography}

Gas exchange measurements were conducted with a portable LI-6400XT (LI-COR Inc., Lincoln, Nebraska, USA) IRGA system equipped with a standard leaf chamber and a LED red/blue light source (type 6400-02B). We investigated non-detached, fully expanded and non-senescent leaves of most distal insertion on exposed peripheral twigs in the sun canopy sections, while the leaves of the shade crowns were positioned on branches in the interior of the lower canopy. In the case of the composed leaves of ash (Fraxinus excelsior), we measured gas exchange on fully expanded leaflets of the middle part of the leaf. On every leaf, the $\mathrm{CO}_{2}$ response was investigated through three $A / C_{\mathrm{i}}$ curves established at leaf 
Table 2 Morphological and functional traits of the five species according to a relative categorisation of species traits in Hölscher (2004), Ellenberg and Leuschner (2010) and others

\begin{tabular}{llllll}
\hline & Fraxinus excelsior & Acer pseudoplatanus & Carpinus betulus & Tilia cordata & Fagus sylvatica \\
\hline Family & Oleaceae & Aceraceae & Betulaceae & Tiliaceae & Fagaceae \\
Max height $[\mathrm{m}]$ & $<40$ & $<40$ & $<35$ & 45 & 50 \\
Architectural model & Rauh & Scarrone & Troll & Troll & Troll \\
Longevity & $250-300$ & $150-600$ & $400(-1,000)$ & $350(-900)$ \\
Shade intensity $^{\text {a }}$ & 3 & 4 & 4 & 4 & 5 \\
Leaf production $^{\text {b }}$ & Single flush & Single flush & Single flush & Single flush & Single flush \\
Leaf area index $^{\mathrm{c}}$ & 5.8 & 5.2 & 8.3 & 7.1 & 7.4 \\
Xylem anatomy $^{\mathrm{d}}$ & Ring & Diffuse & Diffuse & Diffuse & Diffuse \\
Type of mycorrhiza & Arbuscular & Arbuscular & Ekto & Ekto & Ekto \\
Successional status & Early/mid & Mid/late & Mid/late & & Mid/late \\
\hline
\end{tabular}

Extreme values of tree longevity in brackets

${ }^{a}$ Relative assessment of shade intensity below mature tress (3 - moderate, 4-high, 5-very high)

${ }^{\mathrm{b}}$ At maturity

${ }^{\mathrm{c}}$ LAI values from 20 stands (beech) or 2 (1) stands in the other species

${ }^{\mathrm{d}}$ Ring-porous, diffuse-porous

temperatures of 19,25 and $29^{\circ} \mathrm{C}\left( \pm 1^{\circ} \mathrm{C}\right)$ under a photosynthetic photon flux density (PPFD) of $2,000 \mu \mathrm{mol} \mathrm{m} \mathrm{m}^{-2}$. Before the establishment of an $A / C_{\mathrm{i}}$ or light response curve, incident PPFD was stepwise increased to the maximum flux density $\left(2,000 \mu \mathrm{mol} \mathrm{m} \mathrm{m}^{-2}\right)$ and the leaves in the chamber were allowed to adapt to these conditions for at least $10 \mathrm{~min}$ in order to avoid reductions in stomatal conductance. The IRGA channels were matched before every measuring point. For establishing the $A / C_{\mathrm{i}}$ curves, sample $\left[\mathrm{CO}_{2}\right]$ was adjusted to the following 10 concentration steps in the given order: 370 , $30,70,100,200,370,1,200$ and 2,000 ppm $\mathrm{CO}_{2}$. The second $370 \mathrm{ppm}$ measurement was repeated one or two times if the measured assimilation rate deviated from the first measurement at $370 \mathrm{ppm}$. On the same leaves, a light response curve at $25{ }^{\circ} \mathrm{C}$ and $370 \mathrm{ppm} \mathrm{CO}_{2}$ was established in 10 steps: 2,000, 1,200, 500, 200, 100, 50, 20, 0, 0 and $0 \mu \mathrm{mol} \mathrm{m}^{-2} \mathrm{~s}^{-1}$ PPFD (in 2008 in reverse order). The vapour pressure deficit was held constant at ambient conditions during a measuring campaign on a leaf (mean \pm SE for the 15 data sets per species: Fraxinus excelsior, $1.53 \pm 0.02 \mathrm{kPa}$; A. pseudoplatanus, $1.78 \pm 0.02 \mathrm{kPa}$; C. betulus, $1.60 \pm 0.02 \mathrm{kPa}$; T. cordata, $1.64 \pm 0.02 \mathrm{kPa}$; Fagus sylvatica, $1.53 \pm 0.02 \mathrm{kPa}$ ).

For every leaf, a hemispherical photograph (Nikon Coolpix 8400 camera with Nikon Fisheye Converter FC-E9) was taken with the lens positioned exactly at the location where the sampled leaf grew in order to determine canopy openness above a leaf as a proxy of seasonal integrated PPFD during summer at the leaf position.

The measured leaves were brought to the laboratory and scanned to determine leaf area. Thereafter, they were dried $\left(70{ }^{\circ} \mathrm{C}, 48 \mathrm{~h}\right)$ and weighed for determining SLA and analysed for the $\mathrm{C}$ and $\mathrm{N}$ concentrations (element analyzer NA 2500,
CE-Instruments, Rodano, Milano, Italy) and the signature of $\delta^{13} \mathrm{C}$ (element analyzer NA 2500, CE-Instruments, Rodano, Milano, Italy; isotope mass spectrometer Delta plus, Finnigan MAT, Bremen, Germany).

\subsection{Data analysis}

The gas exchange data on the light and $\mathrm{CO}_{2}$ dependence of photosynthesis were analysed using non-linear least-square regressions implemented in Mathematica (version 3.0, Wolfram Research, Champaign, Illinois, USA). For the fitting of the $A / C_{\mathrm{i}}$ curves, the program RACCIA (Fleck 2002) was used which is based on the equations of Farquhar et al. (1980) and Harley and Tenhunen (1991) and Ball et. al. (1987). $J_{\max }$ and $V_{\text {cmax }}$ at the standard temperature of $25^{\circ} \mathrm{C}$ were calculated with a model of the temperature dependence of the photosynthetic parameters that bases on the three $A / C_{\mathrm{i}}$ curves measured at different temperatures. Light response curves were fitted with a nonrectangular hyperbolic function (Ogren and Evans 1993; Thornley 2002) in the same software environment (Eq. 1). In cases where more than one leaf was measured for gas exchange because the first leaf broke away due to strong wind, we used the $\mathrm{N}$ content and leaf area data of the leaf that was analysed for the $25^{\circ} \mathrm{C} A / C_{\mathrm{i}}$ curve. To characterise the photosynthetic capacity of leaves, we chose the parameters light-saturated net photosynthesis rate under ambient $\mathrm{CO}_{2}$ concentration $\left(A_{\max }\right)$, which was derived by non-linear regression with Eq. (1) from the light response curve, and maximum carboxylation rate ( $V_{\text {cmax }}$ from Eq. 2$)$, maximum electron transport rate ( $J_{\max }$ from Eq. 3) and 'dark respiration rate' $\left(R_{\mathrm{d}}\right)$, the latter three being calculated from the $A / C_{\mathrm{i}}$ curves according to the Farquhar model (von Caemmerer and Farquhar 1981) and the approach 
outlined in Brooks and Farquhar (1985). All parameters were expressed alternatively in relation to leaf area, leaf mass and foliar $\mathrm{N}$ content.

The expression for calculating $A_{\max }$ (on leaf area basis) is given by Eq. (1):

$A_{\max }=-\left(\frac{A \alpha \mathrm{PAR}-\xi A^{2}}{A-\alpha \mathrm{PAR}}\right)$

with $A$ being the leaf photosynthetic rate at a given photosynthetically active radiation (PAR), $\xi$ a factor which determines the sharpness in the knee of the non-rectangular hyperbolic curve (set to 0.9; Thornley 2002) and $\alpha$ the initial slope of the light response curve (quantum efficiency of photosynthesis).

$V_{\text {cmax }}$ and $J_{\max }$ (on leaf area basis) were calculated by the Eqs. (2) and (3):

$V_{\mathrm{c} \text { max }}=\frac{\left(A+R_{\mathrm{d}}\right)\left(C_{\mathrm{i}}+K_{\mathrm{c}}\left(\frac{1+O}{K_{\mathrm{c}}}\right)\right)}{\left(1-\frac{\Gamma_{*}}{C_{\mathrm{i}}}\right) C_{\mathrm{i}}}$

$J_{\max }=\frac{\left(A+R_{\mathrm{d}}\right)\left(4 C_{\mathrm{i}}+8 \Gamma_{*} C_{\mathrm{i}}\right)}{4\left(C_{\mathrm{i}}-\Gamma_{*}\right)}$

with $A$ being assimilation rate, $R_{\mathrm{d}}$ leaf dark respiration rate, $C_{\mathrm{i}}$ the intercellular $\mathrm{CO}_{2}$ concentration, $K_{\mathrm{c}}$ the MichaelisMenten constant for carboxylation, $O$ the oxygen concentration at the site of fixation and $\Gamma *$ the $\mathrm{CO}_{2}$ compensation point without consideration of mitochondrial respiration.

The hemispherical photographs were analysed with the program GLA (version 2.0, SFU, Burnaby, Canada) to calculate canopy openness in percent. The following supplementary information was incorporated in the analysis: (1) the growing season lasted from May 1 to September 15 in both years, (2) the beam fraction (fraction of direct radiation, 0.38 ) and the spectral fraction (0.34) were derived from the cloudiness index (0.46) which was calculated from the measured data and (3) the clear-sky transmission coefficient for direct radiation through the atmosphere was set to 0.6 (Frazer et al. 1999).

As we aimed at comparing the five species with respect to sun - shade leaf differences in foliar morphology and physiology, we pooled in the analysis all sun or shade leaves of a species that met the mentioned criteria. All photosynthetic parameters were analysed for a dependence on time (day of the year); none of the parameters showed such a dependency (data not shown). We then compared the data from 2008 with those from 2009 but found no significant interannual difference; thus, both years were pooled. The lower summer precipitation in 2008 than in 2009 and a possible reduction in photosynthetic capacity were not visible in our data. Phenotypic plasticity was calculated as an index (ranging from 0 to 1) for each variable and species as the difference between the maximum and minimum value in the canopy divided by the maximum value (Valladares et al. 2002).

The statistical analyses were carried out with the software $\mathrm{R}$, version 2.0.8 (R Development Core Team 2008) and SAS 9.2 (SAS Institute, Cary, NC, USA). As the assumption of ANOVA and ANCOVA were not met by all data sets, we analysed differences between the five species with a permutation test at a significance level of $p \leq 0.05$ by applying the routine perm in R (using the tests permKS and permTS, exact enumeration) (Fay and Shaw 2010). The Wilcoxon test with a significance level of $p \leq 0.05$ was used for detecting differences between the sun and shade leaves of a species. Differences between means with a significance of $0.05<p \leq 0.1$ were treated as 'marginally significant'.

\section{Results}

3.1 Within-canopy gradients of canopy openness and leaf traits

In the canopies of all five species, canopy openness decreased rapidly from the tree top to a relative canopy height of $\sim 0.7$ (lower sun canopy), where about $10 \%$ of incident radiation was available (Fig. 1a). SLA increased and foliar nitrogen content per area $\left(N_{\mathrm{a}}\right)$ decreased from the canopy top to the base at markedly different slopes in the five species (Fig. 1b, c, Table 3). Steeper SLA increases were found for Fraxinus excelsior and A. pseudoplatanus than for the other three species, while the $N_{\mathrm{a}}$ decrease from top to base was particularly large in $C$. betulus and $T$. cordata and less steep in the other three species. Plotting SLA against canopy openness as a proxy of integrated PPFD during leaf development and exposure gave tight relationships that were described in all five species with functions of the form $y=1 \times(a x+b)^{-1}$ (Fig. 2). Accordingly, the downward decrease in canopy openness was linked to a continuum of leaf morphological types from the typical sun to the typical shade leaves in all species. However, distinct shade leaves with a very high SLA ( $>200$ up to $400 \mathrm{~cm}^{2} \mathrm{~g}^{-1}$ ) were only found in C. betulus, T. cordata and Fagus sylvatica. With SLA values in the range of $130-200 \mathrm{~cm}^{2} \mathrm{~g}^{-1}$, the shade leaves of Fraxinus excelsior and A. pseudoplatanus differed less from the respective sun leaves (difference approx. $100 \mathrm{~cm}^{2} \mathrm{~g}^{-1}$ ), while the sun-shade leaf difference was much more pronounced in the first three species (approx. $200 \mathrm{~cm}^{2} \mathrm{~g}^{-1}$ ). In its average over the canopy, leaf size was largest in Fraxinus excelsior (difference significant to the other species for sun and shade leaves). Significantly larger shade than sun leaves were found in only two species, $T$. cordata and Fagus sylvatica (Table 3). All five species were 
Fig. 1 Relationship between relative height in the canopy and canopy openness (a), SLA (b) or $N_{\mathrm{a}}$ (c) for leaves in the sun (squares), the intermediate (triangle) and the shade crown (black circles) of the five tree species. Given are $p, R^{2}$ and the coefficients $a$ and $b$ for the regression equations (canopy openness: $y=a+\ln x / \mathrm{b}$; SLA and $\left.\mathrm{N}_{\mathrm{a}}: y=a+b x\right)$
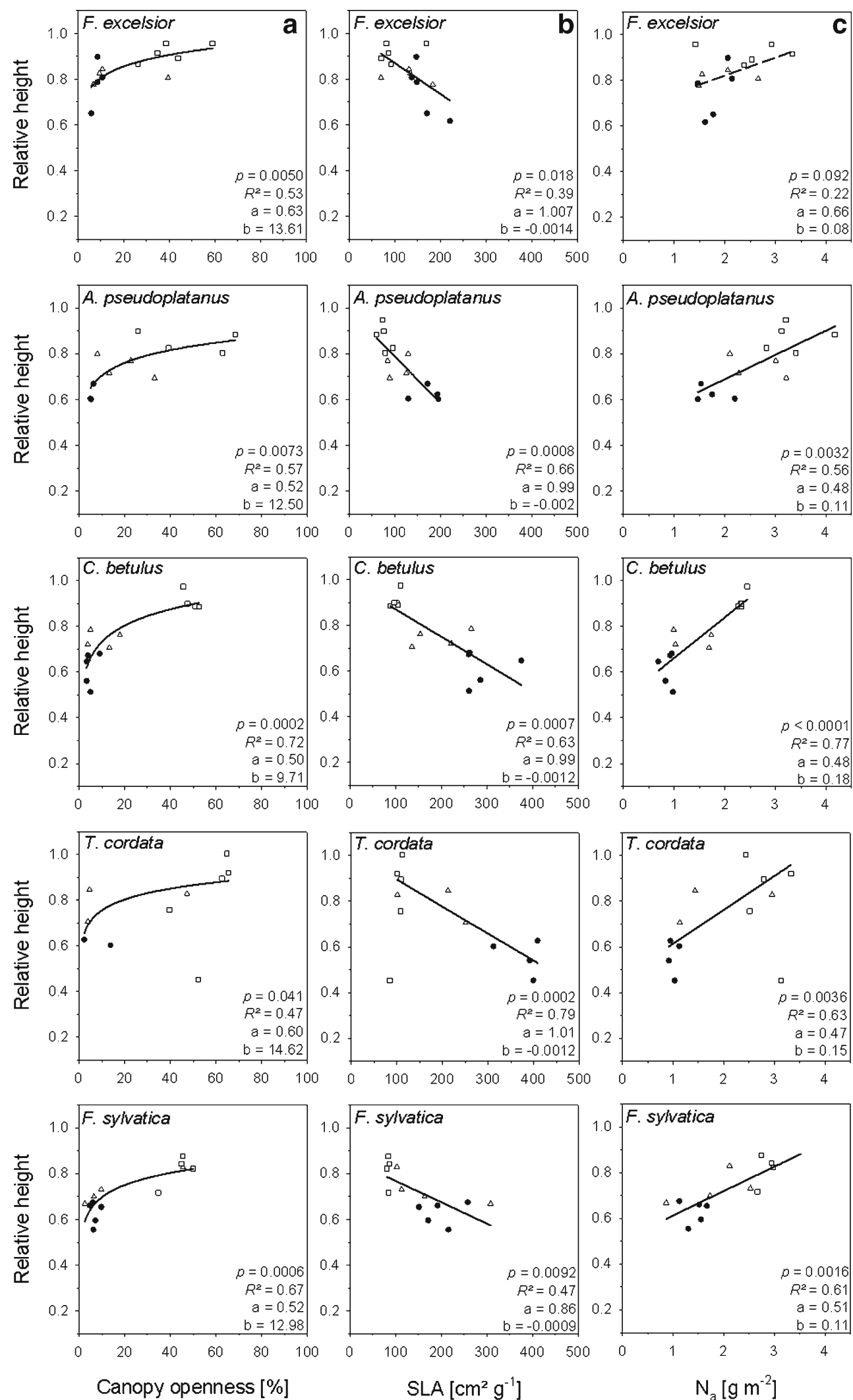

characterised by significantly higher $N_{\mathrm{a}}$ and $\delta^{13} \mathrm{C}$ values differences only marginally significant in Fraxinus excelsiand lower SLA values in their sun than shade leaves $\left(N_{\mathrm{a}}\right.$ 
Table 3 Leaf area, SLA, $N_{\mathrm{a}}$ and $\delta^{13} \mathrm{C}$ signature of typical sun and typical shade leaves of the five species according to the definition based on canopy openness given in "Section 2" (means \pm SE)

\begin{tabular}{|c|c|c|c|c|c|}
\hline Species & $\mathrm{n}$ & Leaf size $\left[\mathrm{cm}^{2}\right]$ & SLA $\left[\mathrm{cm}^{2} \mathrm{~g}^{-1}\right]$ & $\mathrm{N}_{\mathrm{a}}\left[\mathrm{g} \mathrm{m}^{-2}\right]$ & $\delta^{13} \mathrm{C}[\% 0]$ \\
\hline F. excelsior sun & 5 & $289.5 \pm 63.9$ а $\Gamma$ & $99.9 \pm 17.7$ а $\Gamma$ & $2.5 \pm 0.3$ а $\Gamma$ & $-25.7 \pm 0.3$ а $\Gamma$ \\
\hline F. excelsior shade & 5 & $202.0 \pm 54.0 \mathrm{a} \mathrm{A}$ & $164.9 \pm 15.0 \mathrm{~b} \mathrm{~B}$ & $1.5 \pm 0.1 \mathrm{a} \mathrm{A}$ & $-27.8 \pm 0.4$ b B \\
\hline PI & & 0.965 & 0.680 & 0.573 & \\
\hline A. pseudoplatanus sun & 5 & $79.6 \pm 7.9$ a $\Delta$ & $77.2 \pm 5.8$ a $\Gamma$ & $3.3 \pm 0.2 \mathrm{a} \Delta$ & $-26.4 \pm 0.5$ а $\Gamma$ \\
\hline A. pseudoplatanus shade & 4 & $79.9 \pm 11.1$ a B & $172.7 \pm 15.2 \mathrm{~b} \mathrm{~B}$ & $1.7 \pm 0.2 \mathrm{~b} \mathrm{~A}$ & $-30.2 \pm 0.3 \mathrm{~b} \mathrm{~A}$ \\
\hline PI & & 0.475 & 0.691 & 0.648 & \\
\hline C. betulus sun & 5 & $26.5 \pm 3.4$ a $\Delta$ & $100.7 \pm 3.8$ а $\Gamma$ & $2.3 \pm 0.03$ a $\Gamma$ & $-26.0 \pm 0.5$ а $\Gamma$ \\
\hline C. betulus shade & 5 & $27.4 \pm 2.2$ a B & $288.6 \pm 22.2 \mathrm{~b} \mathrm{AC}$ & $0.9 \pm 0.1 \mathrm{~b} \mathrm{~B}$ & $-29.3 \pm 0.2 \mathrm{~b} \mathrm{C}$ \\
\hline PI & & 0.537 & 0.764 & 0.717 & \\
\hline T. cordata sun & 6 & $25.6 \pm 3.5$ a $\Delta$ & $102.7 \pm 4.1$ a $\Gamma$ & $2.9 \pm 0.1$ a $\Delta$ & $-27.7 \pm 0.2$ a $\Delta$ \\
\hline T. cordata shade & 5 & $47.9 \pm 2.8 \mathrm{~b} \mathrm{~B}$ & $349.6 \pm 32.9 \mathrm{~b} \mathrm{~A}$ & $1.1 \pm 0.1 \mathrm{~b} \mathrm{C}$ & $-30.6 \pm 0.3 \mathrm{~b} \mathrm{~A}$ \\
\hline PI & & 0.653 & 0.793 & 0.724 & \\
\hline F. sylvatica sun & 4 & $18.6 \pm 2.8$ a $\Delta$ & $83.5 \pm 1.1$ а $\Gamma$ & $3.0 \pm 0.2 \mathrm{a} \Delta$ & $-26.4 \pm 0.2$ a $\Gamma$ \\
\hline F. sylvatica shade & 5 & $31.1 \pm 2.5 \mathrm{~b} \mathrm{~B}$ & $197.3 \pm 18.5$ b BC & $1.4 \pm 0.1 \mathrm{~b} \mathrm{AC}$ & $-28.7 \pm 0.3 \mathrm{~b} \mathrm{BC}$ \\
\hline PI & & 0.682 & 0.686 & 0.680 & \\
\hline
\end{tabular}

Different lower case letters indicate significant $(p<0.05)$ differences between the sun and shade leaves of a species (Wilcoxon test), different capital letters indicate significant differences between the shade leaves of the species and different Greek letters indicate significant differences between the sun leaves of the species (both tested by permutation test).

PI plasticity index after Valladares et al. (2002)

3.2 Photosynthetic and respiratory activity on a leaf area basis

Despite considerable among-species variation in the three parameters used to characterise photosynthetic capacity
( $V_{\text {cmax,a }}$ - maximum carboxylation rate, $J_{\text {max,a }}$-maximum electron transport rate, $A_{\max , \mathrm{a}}$ - light-saturated net photosynthesis rate), significant species differences in sun leaf photosynthetic capacity were only detected for $V_{\text {cmax,a }}$ between Fraxinus excelsior and $C$. betulus but not between the other
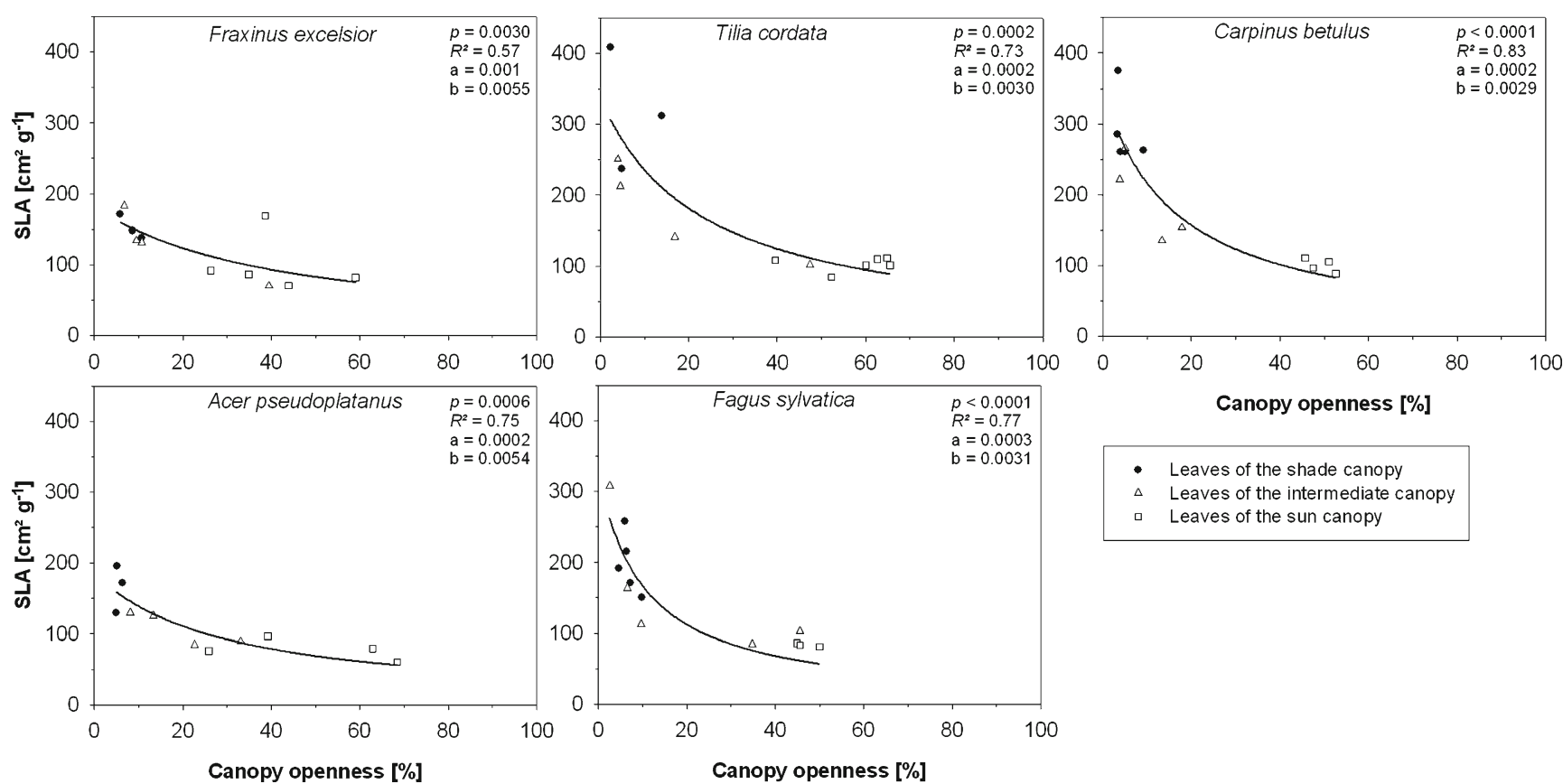

Fig. 2 Dependence of specific leaf area (SLA) on canopy openness in the five tree species. Each point represents one leaf; the symbols indicate the three sun, intermediate and shade crown sections. The hyperbolic regression function has the form: $y=1 \times(a x+b)^{-1}$ 
species. In our sample, a significant species difference was absent for sun leaf $A_{\text {max,a. }}$. The range of species means for sun $V_{\text {cmax,a }}$ values was $56-81 \mu \mathrm{mol} \mathrm{CO}_{2} \mathrm{~m}^{-2} \mathrm{~s}^{-1}$, for $J_{\text {max,a }} 113-$ $174 \mu \mathrm{mol} \mathrm{e} \mathrm{m}^{-2} \mathrm{~s}^{-1}$ and for $A_{\max , \mathrm{a}} 7.6-15.8 \mu \mathrm{mol} \mathrm{CO}_{2} \mathrm{~m}^{-2} \mathrm{~s}^{-1}$ (Fig. 3a-c). However, non-significant trends appeared pointing to somewhat lower $V_{\text {cmax,a }}$ and $A_{\text {max,a }}$ means in the sun leaves of Fagus sylvatica and $C$. betulus and to higher values in Fraxinus excelsior, T. cordata and A. pseudoplatanus. The among-species variation was larger in the shade leaves. A particularly low photosynthetic capacity (all three parameters) was observed in the shade leaves of $C$. betulus (significantly different from Fraxinus excelsior, A. pseudoplatanus or Fagus sylvatica, depending on the parameter), while Fagus sylvatica and T. cordata were intermediate and shade leaves of Fraxinus excelsior and A. pseudoplatanus reached highest values of $V_{\text {cmax }, \mathrm{a}}, J_{\max , \mathrm{a}}$ and $A_{\max , \mathrm{a}}$.

The sun leaves had significantly higher photosynthetic capacities than the shade leaves of a species in $T$. cordata and $C$. betulus (all three parameters), Fraxinus excelsior ( $V_{\text {cmax,a }}$ and $\left.J_{\text {max,a }}\right)$, A.pseudoplatanus $\left(J_{\max , \mathrm{a}}\right)$ and Fagus sylvatica $\left(V_{\text {cmax }, \mathrm{a}}\right)$ (Fig. 3a-c).

Leaf dark respiration $\left(R_{\mathrm{d}, \mathrm{a}}\right)$ as derived from the $A / C_{\mathrm{i}}$ curve varied between 1.1 and $2.5 \mu \mathrm{mol} \mathrm{CO}_{2} \mathrm{~m}^{-2} \mathrm{~s}^{-1}$ in the sun leaves and between 0.7 and $1.5 \mu \mathrm{mol} \mathrm{CO}_{2} \mathrm{~m}^{-2} \mathrm{~s}^{-1}$ in the shade leaves of the five species (species means, Fig. 3d). The sun-shade leaf difference was significant only in Fraxinus excelsior (Fig. 3d)
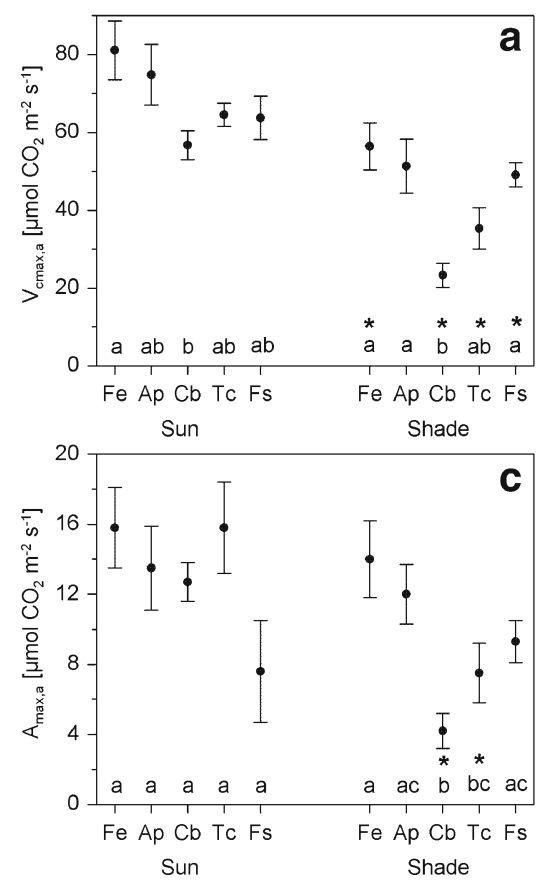

Fig. 3 Parameters of leaf gas exchange for the sun and shade canopies of the five species expressed on a leaf area basis. Only data from typical sun and typical shade leaves according to the definition based on canopy openness given in "Section 2" are considered. $V_{\mathrm{cmax}, \mathrm{a}}$-maximum carboxylation rate (a), $J_{\text {max }, \mathrm{a}}$ - maximum electron transport rate (b), $A_{\text {max }, \mathrm{a}}$ - lightsaturated net photosynthesis rate (c) and $R_{\mathrm{d}, \mathrm{a}}$ - leaf dark respiration rate (d). and showed a non-significant tendency toward smaller $R_{\mathrm{d}, \mathrm{a}}$ values in the shade leaves of Fagus sylvatica.

3.3 Photosynthetic and respiratory activity on a leaf mass basis

In the shade leaves, $C$. betulus had the lowest and $T$. cordata the highest mass-specific photosynthetic activity $\left(V_{\mathrm{cmax}, \mathrm{m}}, J_{\max , \mathrm{m}}\right.$ and $A_{\text {max,m }}$ ) of all species (difference to Tilia significant; Fig. 4a). With respect to shade leaf $A_{\max , \mathrm{m}}, C$. betulus had a significantly lower activity than Fraxinus excelsior, T. cordata and A.pseudoplatanus (Fig. 4c). This species ranking differed from the sequence in area-related activity where the highest shade leaf photosynthetic rates were found in A.pseudoplatanus and Fraxinus excelsior. The mass-related photosynthetic activity of the shade leaves was generally higher than that of the sun leaves, which contrasts with leaf area-related activity. This sunshade leaf difference was significant for $T$. cordata and Fagus sylvatica (all parameters) and A. pseudoplatanus ( $A_{\max , \mathrm{m}}$ only); further, at marginal significance only, shade leaves had a higher $A_{\text {max,m }}$ in $T$. cordata, and a higher $J_{\text {max,m }}$ in A. pseudoplatanus than the respective sun leaves.

Leaf dark respiration on a mass basis $\left(R_{\mathrm{d}, \mathrm{m}}\right)$ was significantly higher in shade than in sun leaves in T. cordata and tended to do so in $C$. betulus as well (Fig. 4d). Concerning $R_{\mathrm{d}, \mathrm{m}}$, no species differences appeared in the sun leaves, while in the
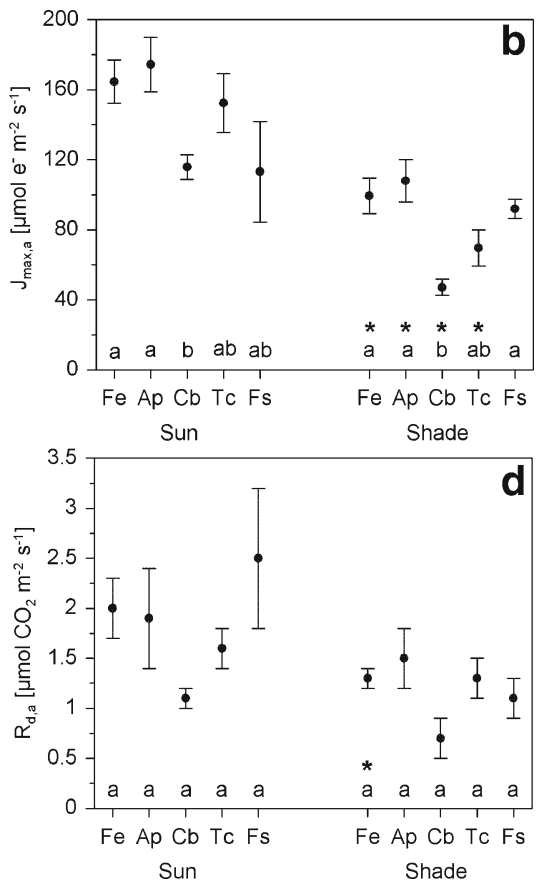

Given are means \pm SE. $n=4-6$ (sun leaves) or 4-5 (shade leaves). Different letters indicate significant $(p<0.05)$ differences between the species in the sun or shade leaf category (permutation test), asterisks mark significant differences between sun and shade leaves of a species (Wilcoxon test). Species acronyms: Fe, Fraxinus excelsior; Ap, Acer pseudoplatanus; $C b$, C. betulus; Tc, T. cordata and Fs, Fagus sylvatica 
Fig. 4 Parameters of leaf gas exchange for the sun and shade canopies of the five species expressed on a leaf mass basis. Only data from typical sun and typical shade leaves according to the definition based on canopy openness given in "Section 2" are considered. $V_{\text {cmax,m }}$-maximum carboxylation rate (a), $J_{\text {max }, \mathrm{m}}$ - maximum electron transport rate (b),

$A_{\text {max,m }}$ - light-saturated net photosynthesis rate (c) and $R_{\mathrm{d}, \mathrm{m}}$-leaf dark respiration rate (d). Given are means \pm SE. For further explanation, see Fig. 3
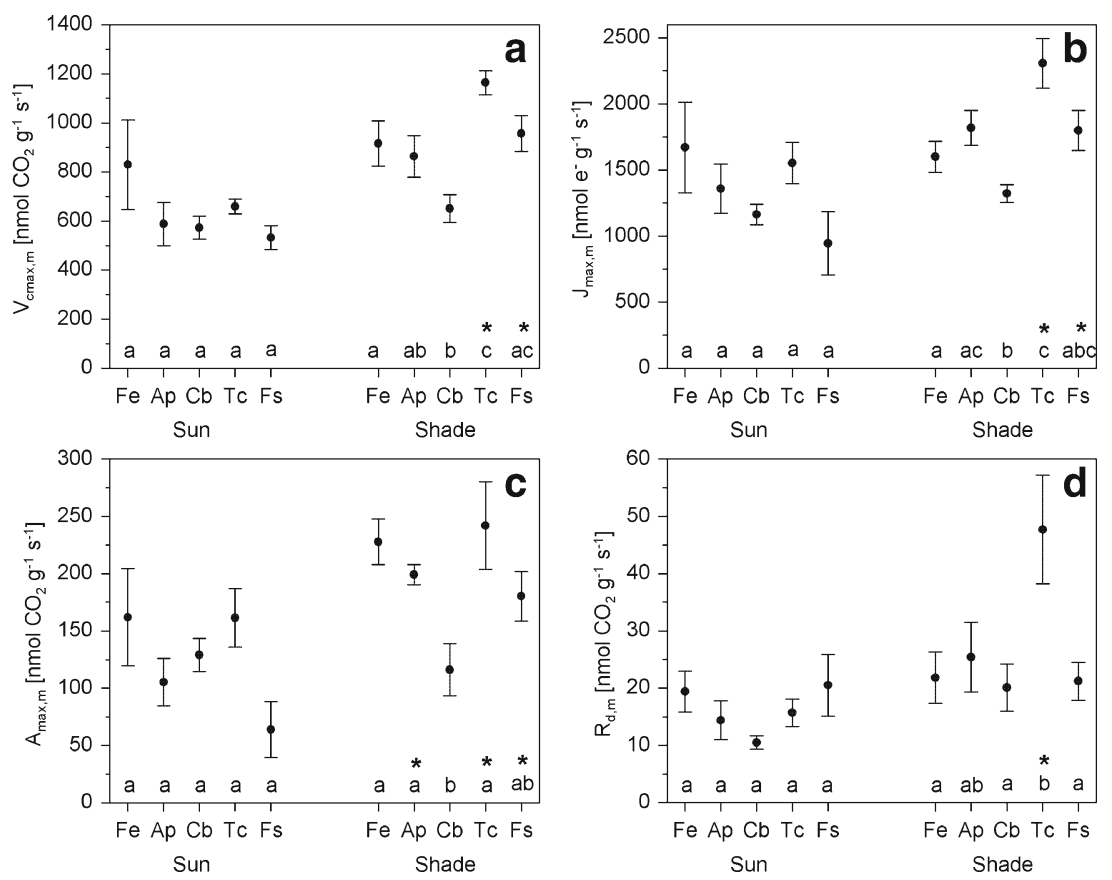

shade leaves, T. cordata reached significantly higher $R_{\mathrm{d}, \mathrm{m}}$ means than Fraxinus excelsior, C. betulus and Fagus sylvatica.

\subsection{Apparent photosynthetic nitrogen use efficiency}

The five species were more similar in terms of their $V_{\text {cmax }}$ and $J_{\max }$ rates scaled to leaf nitrogen than in the leaf area- or leaf mass-related photosynthetic activities. In fact, photosynthetic nitrogen use efficiency (PNUE) did not show any significant differences among the five species, neither in the sun nor the shade leaves (exception, higher sun leaf $A_{\max , \mathrm{N}}$ values in $C$. betulus than in Fagus sylvatica; Fig. 5a-c). However, Fagus sun leaves reached only half of the N-related $A_{\max }$ rate of that of Fraxinus sun leaves (difference not significant). In general, PNUE tended to be higher in the shade than in the sun leaves of a species; this sun-shade leaf difference was significant for Fagus sylvatica $\left(V_{\mathrm{cmax}, \mathrm{N}}, J_{\max , \mathrm{N}}, A_{\max , \mathrm{N}}\right), T$. cordata $\left(V_{\mathrm{cmax}, \mathrm{N}}\right)$ and $A$. pseudoplatanus $\left(A_{\max , \mathrm{N}}\right)$.

Dark respiration expressed per leaf $\mathrm{N}\left(R_{\mathrm{d}, \mathrm{N}}\right.$, Fig. $\left.5 \mathrm{~d}\right)$ was remarkably uniform among the five species (means of 0.45 $1.13 \mu \mathrm{mol} \mathrm{CO} \mathrm{g} \mathrm{N}^{-1} \mathrm{~s}^{-1}$ ) with a significant difference only in $T$. cordata toward higher $\mathrm{N}$-specific respiration rates in shade than in sun leaves.

\section{Discussion}

4.1 Species differences in the functional differentiation between sun and shade leaves

The within-canopy variation in leaf morphological traits indicates that $T$. cordata, $C$. betulus and Fagus sylvatica have a higher low light acclimation potential than Fraxinus excelsior and A. pseudoplatanus. Probably the most influential leaf morphological property that distinguishes Fraxinus excelsior and A. pseudoplatanus from the former three species is the withincanopy variability of specific leaf area (Niinemets et al. 1998). The shade leaves of ash and maple never exceeded SLA values of $200 \mathrm{~cm}^{2} \mathrm{~g}^{-1}$, even though typical sun leaves of all five species were more or less similar with respect to SLA (80 to $120 \mathrm{~cm}^{2} \mathrm{~g}^{-1}$ ). Fraxinus excelsior and A. pseudoplatanus trees lack not only shade leaves with very high SLA but also cast less shade than T. cordata, C. betulus and Fagus sylvatica. It must remain open whether a higher shade canopy light transmissivity as found in ash and maple is primarily narrowing the SLA range of a species, or whether inherent shade leaf architectural constraints are primarily restricting the leaf area in the shade crown of the species, thus reducing below-canopy shade intensity.

The five species also differed markedly with respect to the leaf size difference between sun and shade canopy. Much larger shade than sun leaves were found in T. cordata (on average $87 \%$ larger) and Fagus sylvatica (67\%, both differences significant) while only small (non-significant) or no differences existed in A. pseudoplatanus and $C$. betulus $(<5 \%)$. Remarkably, in Fraxinus excelsior, we found a larger, and not smaller, average leaf size in the sun than in the shade canopy ( $30 \%$ larger area of all leaflets; difference not significant). Leaf size gradients in the canopy often reflect the vertical decrease in light availability in the crown. However, they can also be an expression of variable stress intensities in different parts of the canopy imposed by gradients in the atmospheric saturation deficit and the hydraulic conductivity of the axes in the crown. The surprising leaf size increase in 
Fig. 5 Parameters of leaf gas exchange for the sun and shade canopies of the five species expressed in relation to foliar $\mathrm{N}$ content. Only data from typical sun and typical shade leaves according to the definition based on canopy openness given in "Section 2" are considered. $V_{\text {cmax }, \mathrm{N}}-$ maximum carboxylation rate (a), $J_{\text {max }, \mathrm{N}}-$ maximum electron transport rate (b), $A_{\max , \mathrm{N}}$ - lightsaturated net photosynthesis rate (c) and $R_{\mathrm{d}, \mathrm{N}}$ leaf dark respiration rate (d). Given are means \pm SE. For further explanation, see Fig. 3
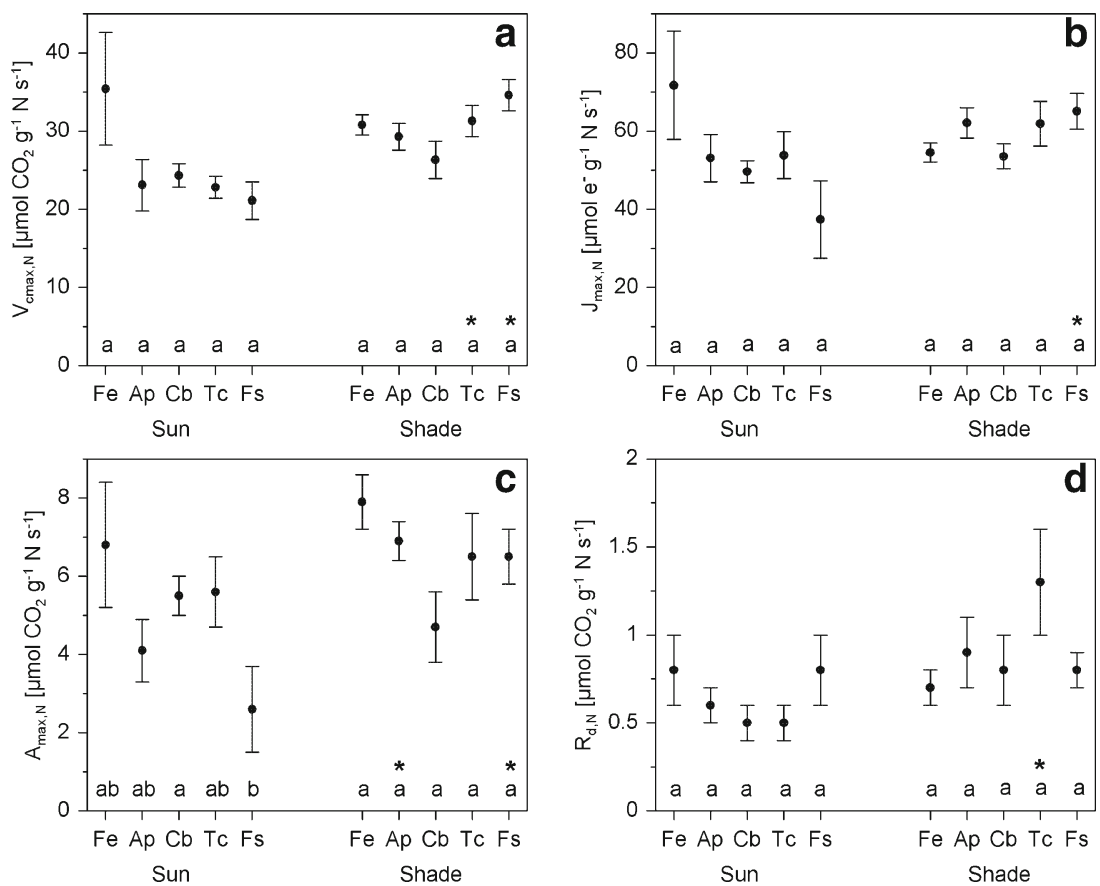

Fraxinus excelsior may either indicate that ash sun leaves have a low susceptibility to drought and/or heat stress, or that the hydraulic architecture of this ring-porous species largely reduces the risk of water shortage and hydraulic failure in top canopy branches. Experiments are needed to distinguish between light and water status effects on leaf size development. Irrespective of the underlying causes, the specific leaf size patterns in ash are further support for the conclusion that this species has no morphologically distinct shade canopy and is exhibiting an intermediate position between typical pioneer and mid-successional trees.

The rather sharp distinction in terms of leaf morphological acclimation between Fraxinus excelsior and A. pseudoplatanus on the one side, and T. cordata, C. betulus and Fagus sylvatica on the other side, is only partly reflected by the data on photosynthetic capacity. Four of the five species (including Fraxinus excelsior) showed pieces of evidence for an effective acclimation of leaf photosynthetic activity and/or leaf dark respiration rate to the reduced light availability in the lower canopy, either by exhibiting relatively high $A_{\text {max,m }}$ rates or reduced $R_{\mathrm{d}, \mathrm{a}}$ rates (as in Fraxinus excelsior). Both traits may help to improve the $\mathrm{C}$ balance of the shade leaves. An exception was $C$. betulus which appeared to be poorly acclimated to low light in its leaf physiology despite much thinner (but not larger) shade than sun leaves. Thus, physiological acclimation to low light may occur even when only moderate or low leaf morphological modification occurs (as in Fraxinus excelsior and $A$. pseudoplatanus), but morphological acclimation may also take place without distinct physiological modifications (as in C. betulus).

Exposed sun leaves of Fraxinus, Tilia, Carpinus and Acer at $25-30 \mathrm{~m}$ height in the canopy reached mean $A_{\text {max,a }}$ rates between 12.7 and $15.8 \mu \mathrm{mol} \mathrm{CO}_{2} \mathrm{~m}^{-2} \mathrm{~s}^{-1}$ which is higher than photosynthetic capacities reported for late-successional temperate broad-leaved trees $\left(6-12 \mu \mathrm{mol} \mathrm{CO}_{2} \mathrm{~m}^{-2} \mathrm{~s}^{-1}\right)$ but is in the lower range of $A_{\text {max,a }}$ rates thought to be characteristic for fast-growing pioneer species $\left(12-25 \mu \mathrm{mol} \mathrm{CO}_{2} \mathrm{~m}^{-2} \mathrm{~s}^{-1}\right.$; Ellenberg and Leuschner 2010; Larcher 1994). Other studies with mature trees of the four mentioned genera showed comparable sun leaf $A_{\text {max,a }}$ rates in the case of temperate Fraxinus species (9-20 $\mu \mathrm{mol} \mathrm{CO} \mathrm{CO}_{2} \mathrm{~m}^{-2} \mathrm{~s}^{-1}$; Bassow and Bazzaz 1997; Hölscher 2004), but somewhat lower rates in case of temperate Tilia species $\left(9-13 \mu \mathrm{mol} \mathrm{CO} \mathrm{CO}^{-2} \mathrm{~s}^{-1}\right.$; Hölscher 2004; Leuzinger et al. 2005; Urban et al. 2007), C. betulus (8$14 \mu \mathrm{mol} \mathrm{CO} \mathrm{m}^{-2} \mathrm{~s}^{-1}$, Hölscher 2004; Leuzinger et al. 2005) and Acer species $\left(7-13 \mu \mathrm{mol} \mathrm{CO}_{2} \mathrm{~m}^{-2} \mathrm{~s}^{-1}\right.$; Bassow and Bazzaz 1997; Hölscher 2004; Jones and Thomas 2007; Urban et al. 2007). Not all of the cited studies measured $A_{\text {max,a }}$ in the exposed uppermost branches of the sun canopy of tall trees, as in the present study. This discrepancy may be one reason for the somewhat lower sun leaf values reported on average in the literature.

The relatively low sun leaf $A_{\max , a}$ rates found for Fagus sylvatica in our study (mean, $7.6 \mu \mathrm{mol} \mathrm{CO} \mathrm{CO}^{-2} \mathrm{~s}^{-1}$ ) match only partly with the available literature data, where a wide range of values between 6 and $>16 \mu \mathrm{mol} \mathrm{CO} \mathrm{CO}_{2} \mathrm{~m}^{-2} \mathrm{~s}^{-1}$ has been reported for adult beech trees (Leuzinger et al. 2005; Lichtenthaler et al. 1981; Schulze 1970; Urban et al. 2007). The relatively low $A_{\text {max,a }}$ values in the Hainich forest might in part be the result of photoinhibition or drought-induced stomatal limitation of photosynthesis in the sun crown of Fagus. We found a comparatively low leaf conductance in beech sun leaves $\left(<0.1 \mathrm{~mol} \mathrm{H}_{2} \mathrm{O} \mathrm{m}^{-2} \mathrm{~s}^{-1}\right)$ on several measuring days. 
The among-species variation in $A_{\text {max,a }}$ was larger in the shade leaves than in the sun leaves (range of species means, $4.2-14.0$ vs. $7.6-15.8 \mu \mathrm{mol} \mathrm{CO}_{2} \mathrm{~m}^{-2} \mathrm{~s}^{-1}$ ). Relatively high shade leaf photosynthetic capacities were reached by early/mid-successional ash but also by the mid/late-successional species $A$. pseudoplatanus. One factor that certainly has contributed to the apparent $A_{\max }$ uniformity in the sun canopies of the five species is that the light climate is more similar among the species in the uppermost sun crown than in the lower shade canopies.

The foliar $\delta^{13} \mathrm{C}$ signatures support the view that the gas exchange patterns of the foliage must be more similar among the species than leaf morphology. $\delta^{13} \mathrm{C}$ showed no clear difference between the two groups of species, neither in the sun nor the shade leaves, and all species had by $2-3 \%$ lower $\delta^{13} \mathrm{C}$ values in their shade leaves compared to the sun leaves. This apparent uniformity may indicate that the leaves of the five species are exposed to rather similar microclimatic gradients from canopy top to bottom which seem to overrule any species-specific differences in leaf physiology.

\subsection{Within-canopy variation in photosynthetic capacity}

We found two general assumptions of the sun/shade leaf paradigm (e.g. Niinemets 2010; Valladares and Niinemets 2008; Walters 2005) not or only partly supported by our data. First, contrary to the frequent observation that massspecific photosynthetic parameters vary only little with light availability (Ellsworth and Reich 1993; Niinemets et al. 1998 ), $V_{\text {cmax,m }}$ and $J_{\text {max,m }}$ were generally higher in the shade than in the sun leaves of our species (significant in two species, tendencies in one further species) indicating higher concentrations and activity of photosynthetic enzymes per leaf dry mass in the shade foliage. A generally higher massspecific shade leaf photosynthetic activity was also found for $A_{\text {max,m }}$, i.e. photosynthetic capacity under the influence of environmental constraints. With respect to mass-specific $A_{\max }$, the literature gives no coherent picture of sun/shade leaf differences in temperate trees. While several authors reported higher rates in sun leaves, e.g. Lichtenthaler et al. (1981) in Fagus sylvatica and Jones and Thomas (2007) in Acer saccharum, others reported the opposite. For example, Masarovicova and Stefancik (1990) found in Fagus sylvatica a slightly lower $A_{\max , \mathrm{m}}$ in sun than in shade leaves.

Second, due to the comparatively high $A_{\text {max,m }}$ rates measured in the shade leaves, three species (Fraxinus excelsior, $A$. pseudoplatanus and Fagus sylvatica) had equally high areaspecific $A_{\max }$ rates in the shade and the sun leaves despite a substantially smaller SLA of the latter. Sun leaf maximum assimilation rate per leaf area was only in $T$. cordata and $C$. betulus significantly higher than shade leaf $A_{\max }$.
Several explanations for this surprising result might be possible:

1. The $A_{\max } / \mathrm{N}$ ratio (instantaneous photosynthetic $\mathrm{N}$ use efficiency) of shade leaves was significantly higher than that of sun leaves in two species and tended to be higher in another one, perhaps due to a smaller mesophyll resistance to $\mathrm{CO}_{2}$ diffusion in shade leaves with thinner cell walls (Tholen and Zhu 2011). More empirical data on mesophyll conductance for $\mathrm{CO}_{2}$ comparing different leaf types and tree species are needed.

2. Drought-sensitive species such as Fagus sylvatica (Köcher et al. 2009) may suffer from a temporarily reduced photosynthetic capacity due to photoinhibition and/or drought stress in the sun canopy. Leaf conductance measurements in sun canopy leaves of beech during summer dry spells showed temporary reductions in leaf conductance and actual photosynthetic capacity on hot summer days in the Hainich forest (P. Köcher, unpublished data) as it was observed in the uppermost sun leaves of other Central European Fagus sylvatica stands (e.g. Kutsch et al. 2001). However, we obtained no indication of a lasting reduction in $J_{\max }$ or $V_{\text {cmax }}$ in dry spells, i.e. a reduction in the quantity and activity of photosynthetic enzymes in the leaf.

3. Sun flecks tend to weaken the vertical within-canopy gradients of light availability and photosynthetic capacity on clear days, thereby reducing the contrast between sun and shade leaves (dePury and Farquhar 1997). However, this effect might act in a similar way in all investigated tree species.

\subsection{Factors that may determine the formation of a shade canopy}

Different plant traits might determine a tree species' capability to produce and maintain acclimated shade leaves which can operate with a positive $\mathrm{C}$ balance under very low irradiances (<approx. $10 \%$ of incident radiation) and simultaneously are casting deep shade on the forest floor (Ellenberg and Leuschner 2010). Producing shade leaves may have advantages with respect to productivity because trees with a distinct shade canopy typically produce larger leaf areas (Falster and Westoby 2003) which may result in larger carbon gain and higher relative growth rates (Sims et al. 1994; Valladares and Niinemets 2008). Further, a shade canopy can be a very effective means for suppressing competitors (Ellenberg and Leuschner 2010). However, the formation of a shade canopy may also have disadvantages for the tree, notably a higher drought sensitivity or increased susceptibility to leaf herbivory (Hallik et al. 2009; Valladares and Niinemets 2008).

It appears that different temperate broad-leaved tree species possess contrasting upper SLA limits (e.g. 200 or 
$400 \mathrm{~cm}^{2} \mathrm{~g}^{-1}$ ) that cannot be exceeded because a minimum of sclerenchymatic structure in the lamina is needed for stability, for counteracting herbivore attack and for withstanding drought. The production of very thin (and often large) shade leaves with highly efficient light harvesting may indeed conflict with a species' water and nutrient economy. Screening of data bases revealed that temperate tree species that produce leaves with high SLA are typically more shade-tolerant and more effective in light harvesting but they are also more drought susceptible (Hallik et al. 2009). In support of such a trade-off, Fagus sylvatica with its well-developed shade canopy is known to be more drought-sensitive than Fraxinus excelsior, C. betulus and T. cordata (Köcher et al. 2009) with the latter species' distribution ranges extending toward the summer dry, more continental regions of Europe (Ellenberg and Leuschner 2010).

The acquisition and utilisation strategies for nitrogen may differ substantially between coexisting broad-leaved tree species which possibly may have consequences for the capability to produce shade leaves (Ellenberg and Leuschner 2010; Wallenda et al. 2000). In our study, the shade leaves of all five species had higher mass-specific $\mathrm{N}$ contents than the respective sun leaves (data not shown). Thus, when the fraction of shade leaf mass in total leaf mass is increased, a higher $\mathrm{N}$ demand for leaf area development is a consequence.

We speculate that it may be a question of $\mathrm{N}$ availability whether the formation of an extended shade canopy is possible or not, even though two of the five species ( $A$. pseudoplatanus and Fagus sylvatica) had higher apparent photosynthetic $\mathrm{N}$ use efficiencies $\left(A_{\max , \mathrm{N}}\right)$ in their shade leaves as compared to the sun leaves. The role of $\mathrm{N}$ availability for the competitive ability of trees that form distinct shade canopies is not clear yet, however. Niinemets (2010) suggested that trees with continuous leaf production (as many pioneer trees) should be capable of only moderate low light acclimation because the average leaf is shorter lived than in trees with a single leaf flush, and continuous leaf death inevitably results in losses of chlorophyll and $\mathrm{N}$. While N-limited environments should promote plants with longer lived leaves and thus with a greater light acclimation potential, $\mathrm{N}$ shortage could also restrict the development of a distinct shade crown, when this canopy type is associated with a higher leaf area index and thus with higher $\mathrm{C}$ and $\mathrm{N}$ investments in the canopy per ground area.

It is possible that the constancy of the light climate is a more decisive factor for shade leaf production than $\mathrm{N}$ availability. Fast-growing canopies should mainly produce sun leaves with higher leaf turnover allowing for a more dynamic response to changing light climates during ontogenesis than is possible in trees with distinct shade canopies. This may suggest that the formation of distinct shade canopies should only be possible in stands where intensive light competition has already resulted in a stabilised community composition with only reduced temporal variation in light availability inside the canopy. In our tree species sample, ash is a species which often grows in stand development stages with dynamic change in light availability where highly adapted shade leaves may not be an advantage (Gregor and Seidling 1997).

Any generalisation about functional differences between sun- and shade-acclimated leaves must consider the time horizon of low light acclimation. Different results may be obtained when comparing the leaves of juvenile trees that were grown under different irradiances or when contrasting sun leaves with shade leaves within the canopy of a single tall tree. In the first case, the low light acclimation of independent leaves with similar position on the shoot of different plants is analysed, while the second approach compares leaves growing on the same tree individual with presumed physiological interactions between sun and shade canopy. A further distinction is needed between trees that produce their leaves in a single leaf flush at the beginning of the growing season (such as the five species of the study) and fast-growing pioneer trees with continuous leaf development (e.g. Populus). The former possess sun and shade leaves of similar age along a steep within-canopy light gradient, while, in the latter, the shade leaves typically have a higher age than the sun leaves because the leaves at lower canopy height were produced earlier and are increasingly overtopped by newly formed branches and shaded by more recent sun leaves.

Our study investigated the within-canopy low light acclimation potential of the leaves of tall trees in a closed stand, i.e. under natural conditions. The leaves were mostly of similar age because all species were mid- to late-successional species with single-flush leaf phenology. While we found clear species differences in the low light acclimation potential, we recognise that the steepness of the vertical light gradient in the canopy differs between the five species because radiation extinction in the canopy is largely determined by speciesspecific foliage distribution and light interception properties. We see the strength of our study in the fact that all 26 examined trees of different species grew in close proximity to each other in a closed stand which ensures similar overall climatic and edaphic conditions and thus allows to identify species differences in light acclimation under natural conditions. Clearly, every tree creates a specific environment in its crown through its specific canopy architecture and competitive ability for resources which sets ultimate limits for the comparison of tree species and their adaptive potential to low light.

\section{Conclusions}

From our results, it appears that all five investigated species, be they early/mid-, mid/late- or late-successional species, 
show certain modifications in leaf morphology or physiology in response to reduced light availability in the lower canopy. Our findings match results from other studies showing that plasticity in photosynthetic capacity is often only a minor component in the shade acclimation of trees while SLA, $\mathrm{N}$ allocation and leaf life span are typically more important (Coste et al. 2010; Montpied et al. 2009). The following six leaf-related criteria were found to be particularly informative for quantifying the degree of sun/shade leaf differentiation in our five species: (1) shade leaf SLA does exceed $200 \mathrm{~cm}^{2} \mathrm{~g}^{-1}$; sun and shade leaves differ two to threefold in SLA; (2) typical shade leaves are at least $20 \%$ larger than sun leaves; (3) the $A_{\text {max,a }}$ rate of shade leaves is similarly high, or only slightly lower, than that of the sun leaves; (4) $A_{\text {max,m }}$ is higher in shade than in sun leaves; (5) the apparent photosynthetic $\mathrm{N}$ use efficiency is higher in shade than in sun leaves; and (6) the specific dark respiration rate of shade leaves is low $\left(R_{\mathrm{d}, \mathrm{a}}\right.$ lower in shade than in sun leaves; $R_{\mathrm{d}, \mathrm{m}}$ similar in sun and shade leaves). None of the five species met all six criteria, but Fagus sylvatica was certainly the species with the 'most complete' leaf-level acclimation to low light in its lower canopy. How the other four species can be ranked according to the degree of their shade leaf acclimation depends on how leaf morphological and physiological modifications are weighted.

When classifying tree species according to their low light acclimation in the lower canopy, it may be straightforward to consider not only leaf-level traits but to consult whole-canopy and stand-level properties as decision criteria as well (Niinemets 2010). The canopy architecture in the lower crown may be an important attribute. The existence of a 'monolayer'-type branching system in the shade canopy with regular spatial foliage distribution and more efficient light harvesting as compared to the 'multilayer' system may be a useful parameter indicating a marked sun/shade canopy differentiation within a canopy. Typical monolayer branching patterns in the shade canopy are characteristic for Fagus sylvatica and $T$. cordata and, to a lesser extent, for A. pseudoplatanus and $C$. betulus. In contrast, the canopy of Fraxinus excelsior reveals a multilayer structure not only in the upper but also the lower canopy section.

Canopy transmissivity for light is another useful criterion for identifying trees with a high degree of low light acclimation. Measurements of transmitted photosynthetically active radiation under closed monospecific stands of Fagus sylvatica, $T$. cordata and C. betulus gave average irradiances in the range of $0.5-3 \%$ relative to incident radiation (Ellenberg and Leuschner 2010), which is somewhat lower than under $A$. pseudoplatanus canopies (approximate range 2-5 \%) and much lower than under Fraxinus excelsior stands ( $>5 \%$, Leuschner, unpublished data). This information from canopy architecture and radiation interception studies may indicate that the five species are representing the following sequence of decreasing low light acclimation in their shade crowns: Fagus sylvatica $>$ T. cordata, C. betulus $>$ A. pseudoplatanus $>$ Fraxinus excelsior.

Acknowledgments We thank all members of the Göttingen Experimental Botanical Garden (particularly Dirk Deilke and Ulrich Werder) and the student helpers for their support in operating the lifter in the forest. The authors thank the administration of Hainich National Park (especially Jens Wilhelm) for the collaboration and granting access to the forest sites, Paul Köcher for the fruitful cooperation, Professor Zucchini (University of Göttingen) for advice in the statistical analysis and Christina Langenbruch for comments on the manuscript.

Funding This research was conducted in the framework of 'Graduiertenkolleg 1086: The Role of Biodiversity for Biogeochemical Cycles and Biotic Interactions in Temperate Deciduous Forests'. The financial support granted by DFG is gratefully acknowledged.

\section{References}

Ball JT, Woodrow IE, Berry JA (1987) A model predicting stomatal conductance and its contribution to the control of photosynthesis under different environmental conditions. In: Biggins J (ed) Progress in photosynthesis research IV. Martinus Nijhof, Dordrecht, pp 221-234

Bassow SL, Bazzaz FA (1997) Intra- and inter-specific variation in canopy photosynthesis in a mixed deciduous forest. Oecologia 109:507-515

Bazzaz FA (1979) Physiological ecology of plant succession. Annu Rev Ecol Syst 10:351-371

Brooks A, Farquhar GD (1985) Effect of temperature on the $\mathrm{CO}_{2} / \mathrm{O}_{2}$ specificity of ribulose-1,5-bisphosphate carboxylase oxygenase and the rate of respiration in the light-estimates from gasexchange measurements on spinach. Planta 165:397-406

Coste S, Roggy J-C, Sonnier G, Dreyer E (2010) Similar irradianceelicited plasticity of leaf traits in saplings of 12 tropical rainforest tree species with highly different leaf mass-to-area ratio. Funct Plant Biol 37:1-14

dePury DGG, Farquhar GD (1997) Simple scaling of photosynthesis from leaves to canopies without the errors of big-leaf models. Plant Cell Environ 20:537-557

Ellenberg H, Leuschner C (2010) Vegetation Mitteleuropas mit den Alpen. UTB, Stuttgart

Ellsworth DS, Reich PB (1993) Canopy structure and vertical patterns of photosynthesis and related leaf traits in a deciduous forest. Oecologia 96:169-178

Falster DS, Westoby M (2003) Leaf size and angle vary widely across species: what consequences for light interception? New Phytol 158:509-525

Farquhar GD, von Caemmerer S, Berry JA (1980) A biochemical model of photosynthetic $\mathrm{CO}_{2}$ assimilation in leaves of $\mathrm{C}_{3}$ species. Planta 149:78-90

Fay MP, Shaw PA (2010) Exact and asymptotic weighted logrank tests for interval censored data: the interval $\mathrm{R}$ package. J Stat Softw 36:1-34

Fleck S (2002) Integrated analysis of relationships between 3D-structure, leaf photosynthesis, and branch transpiration of mature Fagus sylvatica and Quercus petraea trees in a mixed forest stand. $\mathrm{PhD}$ thesis, University of Bayreuth, Bayreuth, Germany

Frazer GW, Trofymow JA, Lertzman KP (1999) Canopy openness and leaf area in chronosequences of coastal temperate rainforests. Can J For Res 30:239-256 
Gregor T, Seidling W (1997) 50 years' succession on a woodland clearing in the mountain area of eastern Hesse. Forstwiss Centrbl 116:218-231

Hallik L, Niinemets U, Wright IJ (2009) Are species shade and drought tolerance reflected in leaf-level structural and functional differentiation in Northern Hemisphere temperate woody flora? New Phytol 184:257-274

Harley PC, Tenhunen JD (1991) Modeling the photosynthetic response of $\mathrm{C}_{3}$ leaves to environmental factors. In: Boote KJ, Loomis RS (eds) Modeling crop photosynthesis - from biochemistry to canopy. American Society of Agronomy and Crop Science Society of America, Madison, pp 17-39

Hölscher D (2004) Leaf traits and photosynthetic parameters of saplings and adult trees of co-existing species in a temperate broadleaved forest. Basic Appl Ecol 5:163-172

Jones TA, Thomas SC (2007) Leaf-level acclimation to gap creation in mature Acer saccharum trees. Tree Physiol 27:281-290

Köcher P, Gebauer T, Horna V, Leuschner C (2009) Leaf water status and stem xylem flux in relation to soil drought in five temperate broad-leaved tree species with contrasting water use strategies. Ann For Sci 66:101

Kutsch WL, Herbst M, Vanselow R, Hummelshoj P, Jensen NO, Kappen L (2001) Stomatal acclimation influences water and carbon fluxes of a beech forest in northern Germany. Basic Appl Ecol 2:265-281

Larcher W (1994) Ökophysiologie der Pflanzen. UTB, Stuttgart

Leuzinger S, Zotz G, Asshoff R, Körner C (2005) Responses of deciduous forest trees to severe drought in Central Europe. Tree Physiol 25:641-650

Liburnau, H. Ritter Lorenz v. Hrg (1908) Eckert-Lorenz Lehrbuch der Forstwirtschaft für Waldbau und Försterschulen Band 3, Verlag der k.u.k. Hofbuchndlung T.W. Frick, Wien

Lichtenthaler HK, Buschmann C, Döll M, Fietz H-J, Bach T, Kozel U, Meier D, Rahmsdorf U (1981) Photosynthetic activity, chloroplast ultrastructure, and leaf characteristics of high-light and low-light plants and of sun and shade leaves. Photosynth Res 2:115-141

Masarovicova E, Stefancik L (1990) Some ecophysiological features in sun and shade leaves of tall beech trees. Biol Plant 32:374-387

Montpied P, Granier A, Dreyer E (2009) Seasonal time-course of gradients of photosynthetic capacity and mesophyll conductance to $\mathrm{CO}_{2}$ across a beech (Fagus sylvatica L.) canopy. J Exp Bot 60:2407-2418

Niinemets U (2007) Photosynthesis and resource distribution through plant canopies. Plant Cell Environ 30:1052-1071

Niinemets U (2010) A review of light interception in plant stands from leaf to canopy in different plant functional types and in species with varying shade tolerance. Ecol Res 25:693-714
Niinemets U, Kull O, Tenhunen JD (1998) An analysis of light effects on foliar morphology, physiology, and light interception in temperate deciduous woody species of contrasting shade tolerance. Tree Physiol 18:681-696

Ogren E, Evans JR (1993) Photosynthetic light-response curves. 1. The influence of $\mathrm{CO}_{2}$ partial-pressure and leaf inversion. Planta 189:182-190

Popma J, Bongers F, Werger MJA (1992) Gap-dependence and leaf characteristics of trees in a tropical lowland rain forest in Mexico. Oikos 63:207-214

R Development Core Team (2008) R: a language and environment for statistical computing, R Foundation for Statistical Computing, Vienna, Austria. URL http://www.R-project.org. Accessed 15 May 2012

Schulze ED (1970) Der $\mathrm{CO}_{2}$-Gaswechsel der Buche (Fagus sylvatica L.) in Abhängigkeit von den Klimafaktoren im Freiland. Flora 159:177-232

Sims DA, Gebauer RLE, Pearcy RW (1994) Scaling sun and shade photosynthetic acclimation of Alocasia macrorrhiza to wholeplant performance.2. Simulation of carbon balance and growth at different photon flux densities. Plant Cell Environ 17:889-900

Tholen D, Zhu XG (2011) The mechanistic basis of internal conductance: a theoretical analysis of mesophyll cell photosynthesis and $\mathrm{CO}_{2}$ diffusion. Plant Physiol 156:90-105

Thornley JHM (2002) Instantaneous canopy photosynthesis: analytical expressions for sun and shade leaves based on exponential light decay down the canopy and an acclimated non-rectangular hyperbola for leaf photosynthesis. Ann Bot 89:451-458

Urban O, Kosvancova M, Marek MV, Lichtenthaler HK (2007) Induction of photosynthesis and importance of limitations during the induction phase in sun and shade leaves of five ecologically contrasting tree species from the temperate zone. Tree Physiol 27: $1207-1215$

Valladares F, Niinemets U (2008) Shade tolerance, a key plant feature of complex nature and consequences. Annu Rev Ecol Evol Syst 39:237-257

Valladares F, Chico JM, Aranda I, Balaguer L, Dizengremel P, Manrique E, Dreyer E (2002) The greater seedling high-light tolerance of Quercus robur over Fagus sylvatica is linked to a greater physiological plasticity. Trees 16:395-403

von Caemmerer S, Farquhar GD (1981) Some relationships between the biochemistry of photosynthesis and the gas exchange of leaves. Planta 153:376-387

Wallenda T, Stober C, Hoegbom L, Schinkel H, Georg E, Hoegberg P, Read DJ (2000) Nitrogen uptake processes in roots and mycorrhizas. In: Schulze ED (ed) Carbon and nitrogen cycling in European forest ecosystems. Springer, Berlin, pp 122-143

Walters RG (2005) Towards an understanding of photosynthetic acclimation. J Exp Bot 56:435-447 